\title{
Effects of a calcium deficiency on stomatal conductance and photosynthetic activity of Quercus robur seedlings grown on nutrient solution
}

\author{
M Ridolfi 1, O Roupsard 2, JP Garrec 1, E Dreyer 2* \\ 1 Équipe pollution atmosphérique; \\ 2 Équipe bioclimatologie et écophysiologie, unité d'écophysiologie forestière, \\ Centre de Nancy, Inra, 54280 Champenoux, France
}

(Received 23 November 1994; accepted 29 June 1995)

\begin{abstract}
Summary - The effects of a calcium deficiency on stomatal functions and photosynthesis were investigated in Quercus robur seedlings grown on a nutrient solution. A severe calcium deficiency did not perturb stomatal reactivity to abscisic acid, and stomatal aperture in darkness was only slightly increased. On the other hand, stomatal conductance under full light, and net $\mathrm{CO}_{2}$ assimilation rates decreased to one-half of the controls. A slowdown of stomatal opening during dark-light transitions was detected in the deficient leaves. Low $\mathrm{Ca}^{2+}$ availabilty could reduce the light activation of chloroplastic enzymes involved in organic osmoticum production in the guard cells. The reduction of net $\mathrm{CO}_{2}$ assimilation was associated with a maintenance of the $\mathrm{CO}_{2}$ mole fraction in the substomatal spaces and with a stability of the photochemical efficiency of photosystem II (PS II) in dark-adapted leaves. Combined measurements of gas exchange and photochemical efficiency allowed the computation of the $\mathrm{CO}_{2}$ mole fraction at the site of carboxylation in the chloroplast, which decreased significantly in the Ca-deficient leaves. This result suggests that a lower $\mathrm{CO}_{2}$ availability at the carboxylation site was the major factor limiting $\mathrm{CO}_{2}$ assimilation under calcium deficiency.
\end{abstract}

calcium deficiency / stomata / photosynthesis / chlorophyll fluorescence / Quercus

* Correspondence and reprints

Abbreviations: $A$ : net $\mathrm{CO}_{2}$ assimilation rate $\left(\mu \mathrm{mol} \mathrm{m} \mathrm{m}^{-2} \mathrm{~s}^{-1}\right) ; g_{c}, g_{\mathrm{w}}$ : stomatal conductance to $\mathrm{CO}_{2}$ and to water vapour $\left(\mu \mathrm{mol} \mathrm{m} \mathrm{m}^{-2} \mathrm{~s}^{-1}\right) ; c, c_{c}: \mathrm{CO}_{2}$ mole fractions in the substomatal spaces and in the chloroplast stroma $\left(\mu \mathrm{mol} \mathrm{mol}^{-1}\right) ; g_{\mathrm{m}}$ : mesophyll conductance to $\mathrm{CO}_{2}\left(\mathrm{mmol} \mathrm{m}^{-2} \mathrm{~s}^{-1}\right)$; PFD: photosynthetic photon flux density $\left(\mu \mathrm{mol} \mathrm{m} \mathrm{m}^{-2} \mathrm{~s}^{-1}\right)$; PS II: photosystem II; $F_{\mathrm{v}} / F_{\mathrm{m}}$ : maximal photochemical efficiency of PS II in the dark-adapted state; $\Delta F / F_{\mathrm{m}}$ ': photochemical efficiency of PS II in the light-adapted state; $F_{\mathrm{v}}{ }^{2} / F_{\mathrm{m}}$ ': photochemial efficiency of open PS II reaction centers in the light-adapted state; $J_{\uparrow}$ : total light driven electron flow $\left(\mu \mathrm{mol} \mathrm{m} \mathrm{m}^{-2} \mathrm{~s}^{-1}\right) ; J_{\mathrm{C}}, J_{\mathrm{O}}$ : light driven electron flow devoted to carboxylation and oxygenation of RuBP, respectively ( $\mu \mathrm{mol} \mathrm{m}^{-2} \mathrm{~s}^{-1}$ ); $\mathrm{ABA}$ : abscisic acid; SD: standard deviation. 
Résumé - Influence d'une carence calcique sur le fonctionnement stomatique et l'activité photosynthétique de plants de Quercus robur cultivés en solution nutritive. L'influence d'une carence calcique sur le fonctionnement stomatique et la photosynthèse a été étudiée sur des plants de Quercus robur cultivés en hydroponie. La carence calcique n'a pas affecté la réponse des stomates à l'ABA, et les degrés d'ouverture stomatique enregistrés à l'obscurité n'étaient que légèrement supérieurs à ceux des plantes témoins. En revanche, les conductances stomatiques en présence de lumière ainsi que l'assimilation nette de $\mathrm{CO}_{2}$ des plantes carencées étaient réduites de moitié. De plus, la vitesse d'ouverture des stomates lors d'une transition obscurité-lumière était fortement réduite. La disponibilité en $\mathrm{Ca}^{++}$dans les cellules de garde pourrait limiter la libération d'osmoticum de type organique nécessaire au mouvement d'ouverture. La diminution de photosynthèse était accompagnée d'une stabilité de la concentration en $\mathrm{CO}_{2}$ dans les espaces intercellulaires, et du maintien d'une efficience photochimique maximale du PS II en fin de nuit. La concentration chloroplastique en $\mathrm{CO}_{2}$, calculée à partir de mesures combinées d'échanges gazeux, et d'efficience photochimique du PS II par fluorescence de la chlorophylle, était en revanche significativement plus faible dans les plantes carencées. Ces résultats suggèrent qu'une baisse de la disponibilité en $\mathrm{CO}_{2}$ dans le chloroplaste était le principal facteur limitant de l'assimilation nette de $\mathrm{CO}_{2}$ en situation de carence calcique.

\section{carence calcique / stomate / photosynthèse / fluorescence de la chlorophylle / Quercus}

\section{INTRODUCTION}

Quercus robur $\mathrm{L}$ is among the major species used for timber production in western Europe and is widely distributed in lowland forests all over France. Like many other oak species, it suffered from frequent periods of decline and crown yellowing (Landmann et al, 1993). There is now a wide consensus that drought is probably the major factor inducing such decline processes, in interaction with diverse biotic aggressors (Becker and Lévy, 1982). However, much evidence points also to a decrease of calcium availability due to long-term soil eutrophisation in oak stands (Thimonnier et al, 1994; Lévy et al, 1995). Furthermore, ecological studies indicated a higher requirement in soil nutrients for $Q$ robur than for $Q$ petraea, an other broad-leaved species (Lévy et al, 1992). An analysis of potential dysfunctions induced in $Q$ robur seedlings by reduced $\mathrm{Ca}^{2+}$ supply was therefore undertaken.

Calcium is involved in many physiological processes of higher plants. High Ca contents occur in the cell wall, in association to pectins, and $\mathrm{Ca}^{2+}$ operates as a second messenger in the regulation of diverse metabolic processes. Indeed, variations of cytosolic-free $\mathrm{Ca}^{2+}$ in guard cells are thought to link stomatal movements to the variations in environmental conditions (reviewed by Mansfield et al, 1990). In particular, both absisic acid (ABA) and darkness-induced stomatal closure involve $\mathrm{Ca}^{2+}$ as a second messenger (De Silva et al, 1985; Schwartz, 1985; MacRobbie, 1988; McAinsh et al, 1990). A calcium deficiency may therefore be suspected to affect stomatal movements and as a consequence plant water status and $\mathrm{CO}_{2}$ net assimilation.

Moreover, the existence of a light-mediated $\mathrm{Ca}^{2+}$ uptake in the chloroplast (Moore and Akerman, 1984; Kreimer et al, 1985), resulting in an increase in stromal-free $\mathrm{Ca}^{2+}$, suggests that $\mathrm{Ca}^{2+}$ acts as a regulatory component in photosynthesis. The lightmediated activation of fructose-1,6-bisphosphatase in intact spinach chloroplasts (Kreimer et al, 1988) requires $\mathrm{Ca}^{2+}$ influx into the chloroplast. Likewise, evidence for an activation of the NAD kinase by $\mathrm{Ca}^{2+}$ has been reported (Moore and Akerman, 1984). The existence of specific $\mathrm{Ca}^{2+}$-binding sites at photosystem II (PS II) (Barr et al, 1983) indicates additional roles for $\mathrm{Ca}^{2+}$ within the chloroplast. $\mathrm{Ca}^{2+}$ is required for 
the activity and the stability of the $\mathrm{O}_{2}$-evolving complex of PS II (Mei and Yocum, 1992). Light driven photosynthetic reactions might well be affected by a calcium deficiency.

Thus, it is of major importance from an ecological viewpoint to understand the role of calcium nutrition in influencing stomatal behaviour and photosynthesis. For this reason we assessed the disorders induced by a reduction of calcium availability on stomatal sensitivity to different stimuli (ie, darkness, light and $A B A$ ) on $Q$ robur seedlings grown in a nutrient solution. We also searched for a limitation of $\mathrm{CO}_{2}$ uptake with calcium deficiency. To evaluate the nature of disorders induced on photosynthetic processes in oak leaves, we analysed concurrently $\mathrm{CO}_{2}$ assimilation rates, stomatal conductance and photochemical efficiency of PS II. Resistances to $\mathrm{CO}_{2}$ influx into the leaves were estimated via the mole fractions of $\mathrm{CO}_{2}$ in the substomatal spaces and in the chloroplast. Initial and total carboxylation activities of Rubisco were also tested in both control and $\mathrm{Ca}$-deficient plants.

\section{MATERIALS AND METHODS}

Three-month-old seedlings of Quercus robur $\mathrm{L}$ (seed origin: Manoncourt, northeast France) were grown in a climate chamber (PFD $\approx 300 \mu \mathrm{mol}$ $\mathrm{m}^{-2} \mathrm{~s}^{-1}, \mathrm{RH} \approx 60 \%, 22^{\circ} \mathrm{C}, 14 \mathrm{~h}$ photoperiod) on a nutrient solution: macronutrients $(\mathrm{mM}), 0.085$ $\mathrm{NaCl}, 0.54 \mathrm{MgSO}_{4}\left(7 \mathrm{H}_{2} \mathrm{O}\right), 0.276\left(\mathrm{NH}_{4}\right)_{2} \mathrm{SO}_{4}$, $1.05 \mathrm{Ca}\left(\mathrm{NO}_{3}\right)_{2}, 1 \mathrm{KNO}_{3}, 0.25 \mathrm{~K}_{2} \mathrm{HPO}_{4}, 4.85$ $\mathrm{KH}_{2} \mathrm{PO}_{4}$; micronutrients $(\mu \mathrm{M}), 3.64 \mathrm{MnSO}_{4} \mathrm{H}_{2} \mathrm{O}$, $3.06 \mathrm{ZnSO}_{4}\left(7 \mathrm{H}_{2} \mathrm{O}\right), 9.12 \mathrm{H}_{3} \mathrm{BO}_{3}, 0.78 \mathrm{CuSO}_{4}$ $\left(5 \mathrm{H}_{2} \mathrm{O}\right), 0.25 \mathrm{MoO}_{7}\left(\mathrm{NH}_{4}\right)_{2}, 0.1 \mathrm{FeSO}_{4}\left(7 \mathrm{H}_{2} \mathrm{O}\right)$, 0.1 EDTA, $\mathrm{Na}_{2}$. Calcium deficiency was induced by suppressing $\mathrm{Ca}\left(\mathrm{NO}_{3}\right)_{2}$ of the solution and adjusting the $\mathrm{NO}_{3}$ supply with $\mathrm{KNO}_{3}$. Leaves were dried at $65{ }^{\circ} \mathrm{C}$ for $48 \mathrm{~h}$. Samples were wet digested using a $\mathrm{HNO}_{3}-\mathrm{HClO}_{4}$ mixture. $\mathrm{Ca}, \mathrm{Mg}$ and $\mathrm{K}$ were determined by atomic absorption spectrophotometry.

Stomatal density was determined on six leaves for both treatments using a scanning electron microprobe (Cambridge Instruments, Cambridge,
UK). For each leaf, stomata of six squares $(0.04$ $\left.\mathrm{mm}^{2}\right)$ were numerated.

The response of stomata to exogenous $\mathrm{ABA}$ ( \pm 2-cis, 4-trans-abscisic acid, Aldrich-Chemie, Steinheim, Germany) was monitored on a leaf of three plants from each treatment. A twig with six to eight leaves was cut under water, and after stabilisation of stomatal conductance, the shoot was transferred to a fube containing an aqueous solution of ABA $\left(10^{-3} \mathrm{M}\right)$. Stomatal conductance was followed with a porometer (Delta-T Device, MK III, Cambridge, UK).

Chlorophylls were extracted from leaf disks $\left(3 \mathrm{~cm}^{2}\right)$ in $5 \mathrm{~mL}$ of dimethyl-sulphoxide (DMSO) for $90 \mathrm{~min}$ at $65^{\circ} \mathrm{C}$ and determined spectrophotometrically (Barnes et al, 1992).

Initial and total carboxylation activities of Rubisco were assayed spectrophotometrically on desalted extracts of fresh leaves according to Van Oosten et al (1992). Activities were expressed in nanokatal per $\mathrm{mg}$ protein. The soluble protein content of the desalted extract was determined using the Coomassie blue method (Bradford, 1976).

The effects of a dark-light transition on stomatal conductance and photosynthesis were followed in situ successively on four control and four deficient leaves using the gas exchange-chlorophyll a monitoring system described below.

Leaf gas exchange was monitored on single leaves enclosed in an aluminium open-flow chamber $\left(10 \mathrm{~cm}^{2}, \mathrm{LSC} 2, A D C\right.$, Hoddesdon, UK). The drop in partial pressures of $\mathrm{CO}_{2}$ and $\mathrm{H}_{2} \mathrm{O}$ in the chamber was measured with a Binos IR gas analyser (Leybold Heraeus, Germany). The temperature of the chamber $\left(22.5^{\circ} \mathrm{C}\right)$ was controlled by water circulating within the aluminium body. A PFD of $500 \mu \mathrm{mol} \mathrm{m} \mathrm{m}^{-2} \mathrm{~s}^{-1}$ was provided by a slide projector (Halogen lamp, $250 \mathrm{~W}$ ), and measured with a Li-Cor Quantum-Sensor (Li-Cor Inc, USA). $\mathrm{CO}_{2}$ entering the chamber was controlled by an absolute analyser (Mark II, ADC, Hoddesdon, UK) and kept at $350 \mu \mathrm{mol} \mathrm{mol}^{-1}$ using mass flow controllers (FC200, Tylan, USA). Leaf to air water vapour pressure difference was set at $10 \mathrm{~Pa}$ $\mathrm{kPa}^{-1}$. In parallel, chlorophyll a fluorescence (steady-state and light-saturated) was recorded with a pulse amplitude modulated fluorometer (PAM 101 Walz, Effeltrich, Germany), with the distal end of the fibre optics placed at $45^{\circ}$ above the upper leaf surface. Fluorescence signals were used to compute the photochemical efficiency of PS II of dark-adapted leaves $\left(F_{\mathrm{v}} / F_{\mathrm{m}}=\left[F_{\mathrm{m}}-F_{\mathrm{o}}\right] / F_{\mathrm{m}}\right.$, Genty et al, 1987), and of leaves having reached 
steady-state photosynthesis under a PFD of 500 $\mu \mathrm{mol} \mathrm{m} \mathrm{m}^{-2} \mathrm{~s}^{-1}\left(\Delta F / F_{\mathrm{m}}{ }^{\prime}=\left[F_{\mathrm{m}}{ }^{\prime}-F\right] / F_{\mathrm{m}}{ }^{\prime}\right.$, Genty et al, $1989)$. Basic fluorescence $\left(F_{0^{\prime}}\right)$ was recorded immediately after switching off the light and used to compute photochemical efficiency of open PS II reaction centres $\left(F_{\mathrm{v}}{ }^{\prime} / F_{\mathrm{m}}{ }^{\prime}=\left[F_{\mathrm{m}}{ }^{\prime}-F_{\mathrm{o}}{ }^{\prime}\right] / F_{\mathrm{m}}{ }^{\prime}\right.$, Genty et al, 1989). Net $\mathrm{CO}_{2}$ assimilation rates $(A)$, stomatal conductance to $\mathrm{CO}_{2}\left(g_{c}\right)$ or to water vapour $\left(g_{w}\right)$, and the substomatal $\mathrm{CO}_{2}$ concentration $\left(c_{i}\right)$ were calculated following the equation of von Caemmerer and Farquhar (1981). After suitable calibration, fluorescence signals were used to compute total light driven electron flow $\left(J_{T}\right)$, carboxylation $\left(J_{\mathrm{c}}\right)$ and oxygenation $\left(J_{0}\right)$ flows (Peterson, 1989; Valentini et al, 1995). These results were used to derive a $\mathrm{CO}_{2}$ concentration in the chloroplast $\left(c_{c}\right)$ using a Rubisco specificity factor of 95 (for details see Roupsard et al, 1996).

\section{RESULTS}

\section{Nutrient content and plant growth}

The calcium deficiency in the nutrient solution promoted a significant decrease in the $\mathrm{Ca}^{2+}$ content of leaves (fig 1 ): mean concentrations fell to about $30 \%$ of the controls ie, $1.5 \mathrm{mg} \mathrm{gDW}^{-1}$. The magnesium content was lowered to about $60 \%$ of controls but potassium remained similar in both cases, with nevertheless a larger variability among Ca-deficient seedlings.

No obvious effect of the $\mathrm{Ca}^{2+}$ deficiency was detected on growth, which remained in both cases restricted to a unique flush. Neither total leaf area or number of leaves, nor seedling height were reduced (table I). Nevertheless, the $\mathrm{Ca}^{2+}$ deficiency resulted in a typical deformation of the leaf surface in all plants. Contents in chlorophyll $a$ and $b$ were not affected by the treatment (table I).

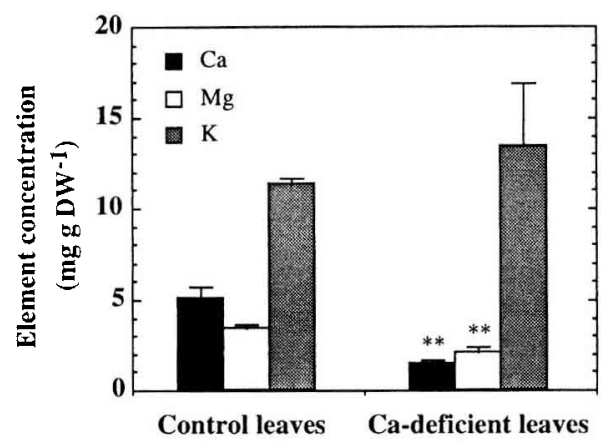

Fig 1. Effects of a Ca-deficiency on $\mathrm{Ca}, \mathrm{Mg}$ and K concentrations in leaves of Quercus robur seedlings grown in a climate chamber $(n=8$ leaves; bars indicate $\pm \mathrm{SD} ; * x<0.01$ ) .

Table I. Effect of a calcium deficiency on plant growth, chlorophyll concentrations and stomatal density of leaves of Quercus robur seedlings $(n=6$; mean value $\pm S D$ ).

Total leaf area $\left(\mathrm{cm}^{2}\right)$

No of leaves

Shoot height $(\mathrm{cm})$

Chlorophyll concentration ( $\mathrm{mg} \mathrm{dm}^{-2}$ ) chlorophyll a chlorophyll b

Stomatal density stomata $\left(\mathrm{mm}^{-2}\right)$

$$
136.8 \pm 31.2
$$

$$
6.0 \pm 1
$$

$11.5 \pm 1.6$

$$
4.4 \pm 0.6
$$$$
1.0 \pm 0.3
$$$$
4.1 \pm 0.8
$$$$
1.1 \pm 0.4
$$

$140.4 \pm 46.0$

$6.0 \pm 1$

$12.8 \pm 2.3$

$390.0 \pm 30$

$360.0 \pm 50$ 


\section{Stomatal movements}

Both treatments exhibited similar stomatal densities (table 1). A supply of ABA via the xylem of control plants induced a stomatal closure with two phases, a fast one followed by a slower one (fig 2). Stomatal conductance reached levels around 0 after $90 \mathrm{~min}$. Ca-deficient leaves were characterised by lower initial stomatal apertures, without any delay in the response to ABA. An almost complete closure was recorded after 20-30

Fig 2. Time course of the response of stomatal conductance $\left(g_{w}\right)$ to the supply of exogenous ABA $\left(10^{-3} \mathrm{M}\right)$ in leaves of control (closed squares) and $\mathrm{Ca}$-deficient (open squares) Quercus robur seedlings. Three time courses were followed for each treatment.

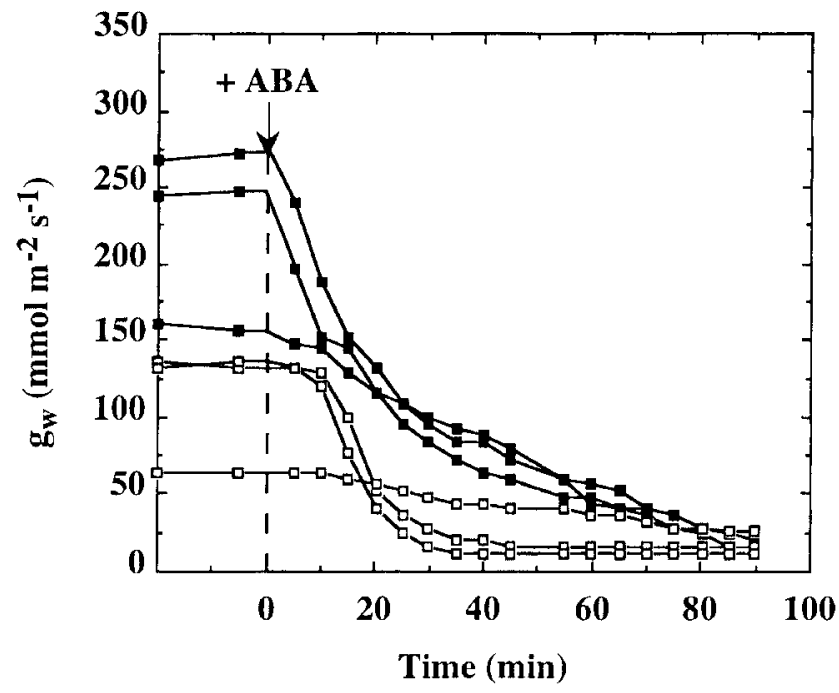

Table II. Mean values $\pm \mathrm{SD}$ of stomatal conductance to $\mathrm{CO}_{2}$ in darkness $\left(g_{\mathrm{c}}\right.$ dark) or under light ( $g_{\mathrm{c}}$ light), and of dark respiration $\left(R_{\mathrm{d}}\right)$, net $\mathrm{CO}_{2}$ assimilation $(A)$, substomatal $\left(C_{\mathrm{i}}\right)$ or chloroplastic $\left(C_{\mathrm{c}}\right)$ mole fractions of $\mathrm{CO}_{2}$ of Quercus robur seedlings.

\section{Control}

$0.1 \pm 0.3$

$72.0 \pm 20.9$

$7.7 \pm 1.4$

$0.3 \pm 0.1$

$6.8 \pm 2.8$

$236.5 \pm 5.8$

$161.0 \pm 29.2$
Ca-deficient plant

$12.7 \pm 3.7$ **

$40.7 \pm 20.1$ *

$21.7 \pm 5.4$ **

$0.7 \pm 0.2$ *

$4.2 \pm 2.1$

$243.1 \pm 5.8$

$115.5 \pm 20.9$ *

PFD: $500 \mu \mathrm{mol} \mathrm{m} \mathrm{m}^{-2} \mathrm{~s}^{-1}\left(n=4 ;{ }^{\star} P<0.05 ;{ }^{\star \star} P<0.01\right)$. 
min. However, Ca-deficient leaves did not present the second, and slower closure phase.

Under darkness, stomatal conductance to $\mathrm{CO}_{2}\left(g_{\mathrm{c}}\right)$ was almost nil in control leaves and slightly higher $\left(5-20 \mathrm{mmol} \mathrm{m}^{-2} \mathrm{~s}^{-1}\right)$ in Ca-deficient leaves (fig 3 , table II). A transition from darkness to a PFD of $500 \mu \mathrm{mol}$ $\mathrm{m}^{-2} \mathrm{~s}^{-1}$ promoted a fast stomatal opening in the leaves of controls, and a much slower one in the Ca-deficient with almost doubled opening half-times (fig 3). Steady-state aperture was achieved after 20-30 min in light for control leaves and only after 40-50 min for Ca-deficient plants. Furthemore, mean steady-state stomatal conductance was lowered by $55 \%$ in Ca-deficient plants (table II).

\section{Regulation of photosynthetic activity}

Dark respiration measured at predawn was almost doubled in Ca-deficient plant (table II). After the onset of irradiance, net $\mathrm{CO}_{2}$ assimilation rates $(A)$ increased in parallel with $g_{C}$ (fig 3). A phase shift in the increase of $A$ was also recorded in Ca-deficient leaves. Likewise, the steady-state value of $A$ in Ca-deficient plants was reduced to half of the control. A unique linear relationship

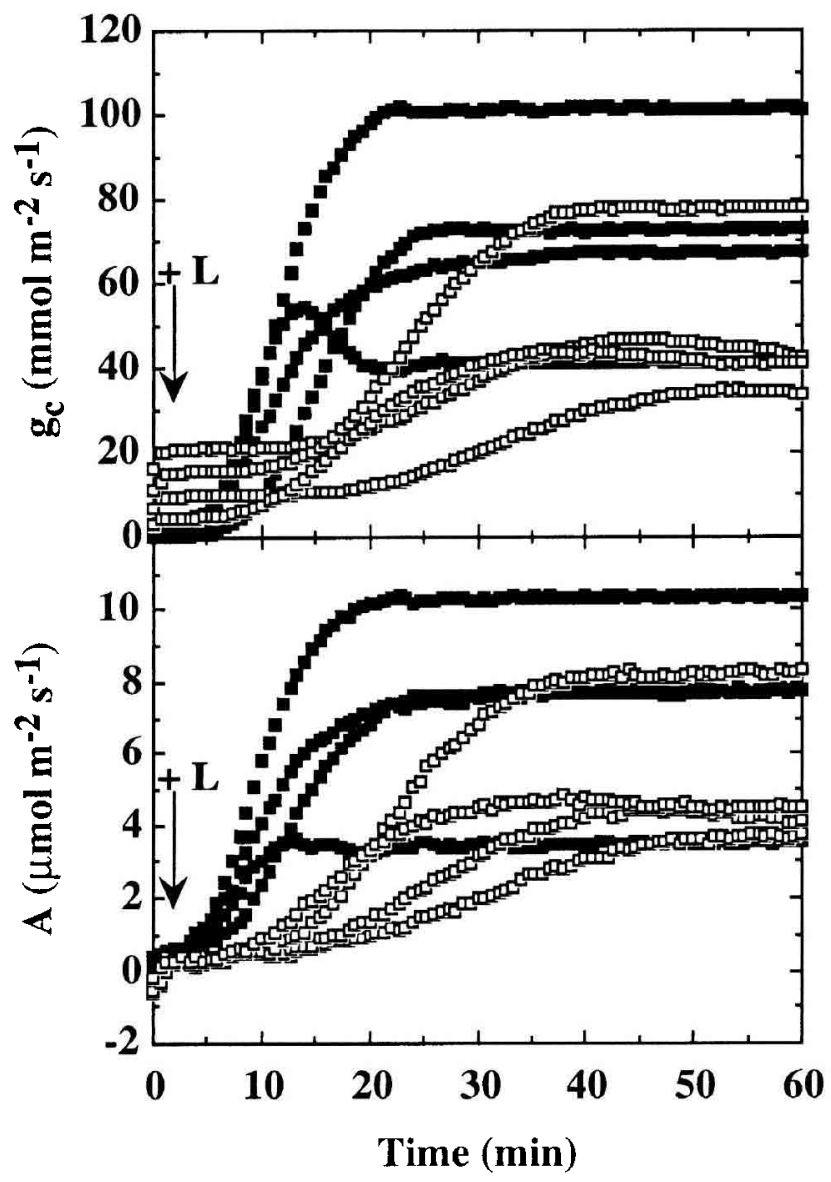

Fig 3. Time course of stomatal conductance to $\mathrm{CO}_{2}$ $\left(g_{\mathrm{c}}\right)$ and of net $\mathrm{CO}_{2}$ assimilation rates $(A)$ during a dark-light transition in leaves of four control (closed squares) and four Ca-deficient (open squares) Quercus robur seedlings. PFD: $500 \mu \mathrm{mol} \mathrm{m}-2 \mathrm{~s}^{-1}$; temperature: $22.5^{\circ} \mathrm{C}$. 
was found between $A$ and the stomatal conductance to water vapour $\left(g_{w}\right)$ at steady state fro both treatments, and the $y$-intercept was not significantly different from zero (fig 4). As a result, the decrease in $A$ was accompanied by the maintenance of the calculated intercellular $\mathrm{CO}_{2}$ mole fraction $\left(c_{i}\right)$ at about $240 \mu \mathrm{mol} \mathrm{mol}^{-1}$ (fig 5, table II).

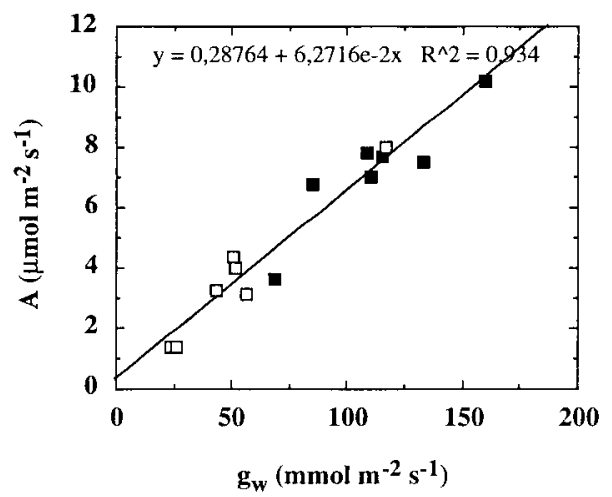

Fig 4. Net assimilation rates $(A)$ as a function of stomatal conductance to water vapour $\left(g_{w}\right)$ in control (closed squares) and Ca-deficient (open squares) leaves of Quercus robur seedlings. PFD: $500 \mu \mathrm{mol} \mathrm{m} \mathrm{m}^{-2} \mathrm{~s}^{-1}$; temperature: $22.5^{\circ} \mathrm{C}$. Each point represents a single measurement at steady state.

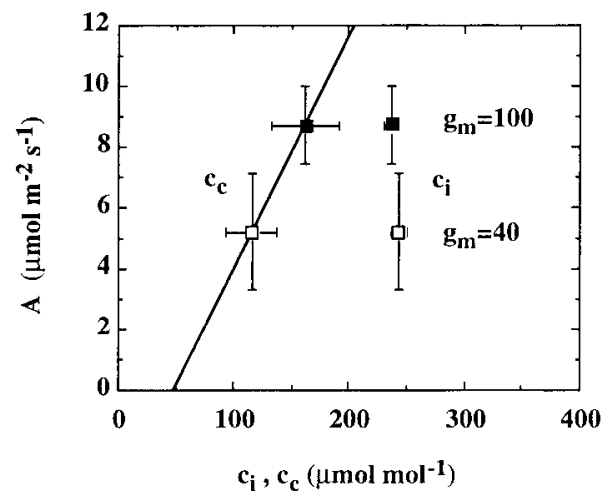

Fig 5. Net $\mathrm{CO}_{2}$ assimilation rates of controls and Ca-deficient leaves, as a function of either substomatal $\left(c_{i}\right)$ or chloroplastic $\left(c_{c}\right) \mathrm{CO}_{2}$ mole fractions. Mesophyll conductance to $\mathrm{CO}_{2}\left(g_{m}\right)$ computed as $A /\left(c_{i}-c_{c}\right)$ is indicated in each case $(n=$ 6 leaves; bars indicate $\pm S D$ ).
The predawn photochemical efficiency of PS II $\left(F_{\mathrm{v}} / F_{\mathrm{m}}\right)$ remained at the almost maximal value of 0.8 in both control and $\mathrm{Ca}$ deficient leaves (fig 6). Likewise, neither the photochemical efficiency of PS II in the light $\left(\Delta F / F_{\mathrm{m}}{ }^{\prime}\right)$, nor the photochemical efficiency of open reaction centers $\left(F_{\mathrm{v}}{ }^{\prime} / F_{\mathrm{m}}{ }^{\prime}\right)$ were significantly reduced by the calcium deficiency. As a result, calculated total light driven electron flows $\left(J_{T}\right)$ remained constant despite the reduced net assimilation. The electron flow devoted to RuBP carboxylation $\left(J_{C}\right)$ was reduced and the one used for RuBP oxygenation $\left(J_{O}\right)$ was amplified. The ratio $J_{C} / J_{O}$ was therefore strongly reduced, yielding a significantly lower calculated $\mathrm{CO}_{2}$ concentration at the carboxylation sites $\left(c_{\mathrm{C}}\right)$

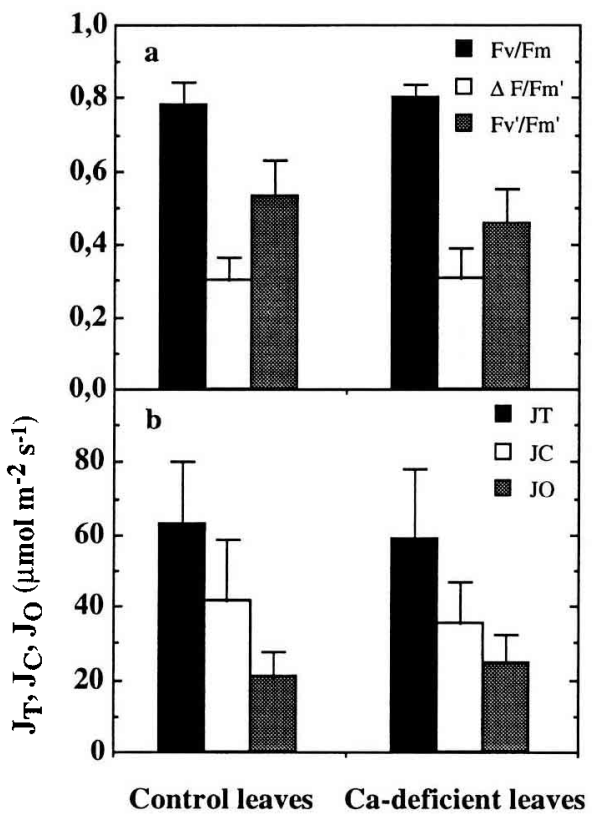

Fig 6. Effects of a Ca-deficiency on (a) the photochemical efficiency of PS II in dark-adapted leaves $\left(F_{\mathrm{v}} / F_{\mathrm{m}}\right)$ and during exposure to a PFD of $500 \mu \mathrm{mol} \mathrm{m}{ }^{-2} \mathrm{~s}^{-1}\left(\Delta F / F_{\mathrm{m}}\right.$ total efficiency; $F_{\mathrm{v}^{\prime}} / F_{\mathrm{m}^{\prime}}$, efficiency of open centers); and (b) on the tota! light driven electron flow $\left(J_{T}\right)$, and the electron flows devoted to RuBP carboxylation $\left(J_{C}\right)$ or oxygenation ( $\left.J_{O}\right)$. PFD: $500 \mu \mathrm{mol} \mathrm{m} \mathrm{m}^{-2} \mathrm{~s}^{-1}$; temperature: $22.5^{\circ} \mathrm{C}(n=4$ leaves; bars indicate $\pm \mathrm{SD})$. 


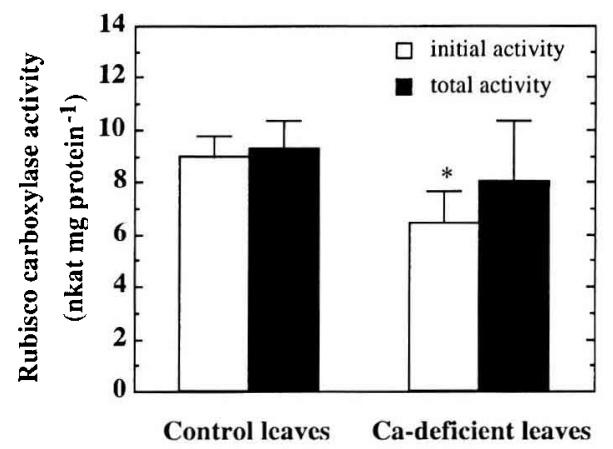

Fig 7. Effects of a Ca-deficiency on initial and total carboxylase activity of Rubisco extracted from leaves of Quercus robur seedlings ( $n=6$ leaves; bars indicate $\pm \mathrm{SD}$ * $P<0.05$ ).

under calcium deficiency: 160 versus 110 $\mu \mathrm{mol} \mathrm{mol}{ }^{-1}(P<0.05$, fig 5 , table II). We computed a mesophyll conductance to $\mathrm{CO}_{2}$ $\left(g_{\mathrm{m}}\right)$ based on the oversimplified model $g_{\mathrm{m}}$ $=A /\left(c_{i}-c_{\mathrm{c}}\right)$, and observed that it decreased significantly in the Ca-deficient plants (100 versus $40 \mathrm{mmol} \mathrm{m}^{-2} \mathrm{~s}^{-1}, P<0.05$, fig 5).

The initial carboxylation activity of Rubisco was high in control plants and close to total activity (activation state: $97 \%$, fig 7 ). The Ca-deficiency resulted in a significant decrease of the initial carboxylation activity $(P<0.05)$, while the total activity of the enzyme was not affected (fig 7 ). The activation state of Rubisco was therefore reduced to $80 \%$ of controls.

\section{DISCUSSION}

The suppression of $\mathrm{Ca}^{2+}$ in the nutrient solution resulted in a very significant decrease in $\mathrm{Ca}$ and $\mathrm{Mg}$ contents in the leaves of Quercus robur seedlings: 1.5 versus 5 and 2 versus $3.4 \mathrm{mg} \mathrm{gDW}^{-1}$, respectively. These residual amounts were probably mobilized from the cotyledons. Deficiency thresholds of leaf content in $\mathrm{Mg}$ are thought to be around 1 and below $5 \mathrm{mg} \mathrm{gDW}^{-1}$ for $\mathrm{Ca}$ (Bonneau, 1988). A national survey of oak forests in France showed that in adult trees, contents in $\mathrm{Mg}$ and $\mathrm{Ca}$ ranged between 1.1 and 2.5 and 5.9 and $11.2 \mathrm{mg} \mathrm{gDW}^{-1}$, respectively (Ulrich and Bonneau, 1994). We may therefore assume that the seedlings presented a strong deficiency in $\mathrm{Ca}$, while $\mathrm{Mg}$ remained above deficiency levels. The observed stability of chlorophyll concentrations was a good confirmation of an almost adequate $\mathrm{Mg}$ content.

Stomata play a key role in regulating the influx of carbon dioxide and the loss of water vapour. Cytosolic-free $\mathrm{Ca}^{2+}$ is thought to be involved in signal transduction linking the variations in environmental conditions to stomatal movements (reviewed by Mansfield et al, 1990). Thus, darkness (Schwartz, 1985) and ABA (De Silva et al, 1985; Mc Ainsh et al, 1990) induce stomatal closure mainly via an increase of cytosolic-free $\mathrm{Ca}^{2+}$ in the guard cells, which in turn inhibits proton efflux (Inoue and Katoh, 1987) and $\mathrm{K}^{+}$ uptake (Blatt et al, 1990), and activates anion efflux (Schroeder and Hagiwara, 1989). The calcium deficiency in oak leaves resulted in an uncomplete stomatal closure under darkness. Thus, we may state that decreased availability of calcium at leaf level probably affected the pool of guard cell $\mathrm{Ca}^{2+}$ and therefore limited the increase in cytosolic $\mathrm{Ca}^{2}+$ necessary for the dark-induced stomatal closure. On the other hand, the stomatal reactivity to $\mathrm{ABA}$, the endogenous growth regulator which is thought to link stomatal responses to water deficit (Davies and Zhang, 1991), was not modified and a complete stomatal closure was always recorded 30 min after ABA supply. A similar discrepancy between the perception by guard cells of darkness versus ABA as the result of calcium deficiency has been previously described in Vicia faba (Ridolfi et al, 1994). ABA supply induced a partial stomatal-closing movement in $\mathrm{Ca}$ - deficient $V$ faba plants, whereas darkness had no effect at all (completely open stomata). Such effects could be related to the fact that dark- 
ness-induced stomatal closure relies on an increase in cytosolic $\mathrm{Ca}^{2+}$, while $\mathrm{ABA}$ induced closure could also involve $\mathrm{Ca}^{2+}$ independent transduction pathways (Gilroy et al, 1991).

The Ca deficiency resulted in an increase of the half-times for stomatal opening from 7.7 to $21.7 \mathrm{~min}$. The values recorded for the control oak seedlings agreed rather well with published data (around $12 \mathrm{~min}$ for Phaseolus, Barradas et al, 1994; 24 min for Commelina communis, Vavasseur et al, 1984; 35 min for Vicia faba, Ridolfi et al, 1994). Water stress, increased temperature and vapour pressure deficits were found to decrease this half-time in Phaseolus vulgaris (Barradas et al, 1994). We do not know of any further report indicating changes in opening half-times in situ in response to environmental constraints.

In addition to this delay in opening, stomatal aperture at steady state was much lower in Ca-deficient leaves. Both effects were not completely expected. Indeed, a decreased availability of $\mathrm{Ca}^{2+}$ in the guard cell cytosol should not directly affect the velocity or the magnitude of light-induced opening, which generally rely on a strong influx of $\mathrm{K}^{+}$. Nevertheless, we have to consider recent studies on epidermal peels or in intact leaves of K-deficient $V$ faba plants showing that $\mathrm{K}+$ uptake into guard cell vacuoles was not always necessary to allow a normal stomatal opening (Poffenroth et al, 1992; Ridolfi et al, 1994). The increase in osmotic potential allowing stomatal opening is the result of three key metabolic processes which do not always act together: i) uptake of $\mathrm{K}^{+}$, balanced by chloride and malate; ii) accumulation of sucrose through photosynthetic carbon fixation; and iii) accumulation of sucrose derived from starch breakdown (Tallman and Zeiger, 1988; Poffenroth et al, 1992; Talbott and Zeiger, 1993). The deficiency induced a decrease in net $\mathrm{CO}_{2}$ assimilation $(A)$ at leaf level to onehalf of the controls. Rubisco and photosyn- thetic carbon reduction pathway enzyme activities have been detected in $V$ faba guard cells (Zemel and Gepstein, 1985; Shimazaki et al, 1989). It can be envisioned that calcium deficiency also reduced the photosynthetic carbon fixation in guard cells. As a result, the amount of soluble sugars (glucose, fructose) required for the osmotic buildup might have been lowered and consequently have reduced stomatal aperture in light.

With regard to net $\mathrm{CO}_{2}$ assimilation rates at leaf level, reductions in $A$ can be the result of reduced $\mathrm{CO}_{2}$ influx or changes in mesophyll capacity for photosynthesis.

Recently, combined measurements of gas exchange and of quantum yield of light conversion by PS II with chlorophyll a fluorescence, showed that the influx of $\mathrm{CO}_{2}$ from substomatal spaces to chloroplast stroma (including gas diffusion and liquid phase fluxes) was an important limiting step for photosynthesis in many tree species (Loreto et al, 1992 ; Epron et al, 1995; Roupsard et al, 1996). Calcium deficiency in oak leaves induced a decrease in $A$ with maintenance of $\mathrm{CO}_{2}$ concentrations in the substomatal spaces $\left(c_{i}\right)$ and a decrease of $\mathrm{CO}_{2}$ at the carboxylation sites $\left(c_{c}\right)$. In contrast, the activation state of Rubisco was reduced to $80 \%$. We may exclude an effect of $\mathrm{Mg}$ availability to explain this decrease as $\mathrm{Mg}$ remained above the threshold levels. A secondary effect of $\mathrm{CO}_{2}$ deprivation on activation state may be more probable.

Our observations suggest that the decrease of $\mathrm{CO}_{2}$ concentration in the chloroplast $\left(c_{\mathrm{C}}\right)$ was the major factor limiting $A$ in Ca-deficient plants. Moreover, the stability of the $\mathrm{CO}_{2}$ concentration in the substomatal spaces would indicate a limitation of $\mathrm{CO}_{2}$ influx from substomatal spaces till chloroplast stroma (reduced internal conductance to $\mathrm{CO}_{2}$ ). Similar results have been obtained with plants submitted to drought (Tourneux and Peltier, 1995; Roupsard et al, 1996). No hypothesis about the physiological mech- 
anisms relating Ca-deficiency and internal conductance to $\mathrm{CO}_{2}$ can yet be formulated. Moreover, artefacts in the computation of $c_{\mid}$like those reported by Terashima et al (1988) with ABA-fed or water-stressed leaves cannot be completely ruled out in this case. Additionnal results would be needed to firmly establish the existence of such nonstomatal limitations in $\mathrm{CO}_{2}$ influx as a response to changing levels of $\mathrm{Ca}$. Interestingly, the observed effects on $c_{\mathrm{C}}$ were obtained while the intrinsinc water use efficiency $\left(A / g_{w}\right.$ ratio) was kept constant, underlining the good coordination between reductions of net assimilation rates and stomatal conductance.

A few ecological consequences of these findings may be drawn. As this severe calcium deficiency did not perturb significantly stomatal reactivity to $\mathrm{ABA}$, and stomatal aperture in darkness was only slightly increased, stomata should still be able to close in response to soil water depletion. Direct correlation between drought-induced decline processes and $\mathrm{Ca}$ deficiency may be excluded. On the other hand, reduced stomatal conductance in light and declining $\mathrm{CO}_{2}$ uptake lead to reductions in tree growth. Further data are needed to firmly establish the relationships existing between the known effects of $\mathrm{Ca}^{2+}$ on the regulation of individual metabolic steps, and their consequences for photosynthesis and water relations at an integrated leaf level.

\section{ACKNOWLEDGMENTS}

The authors thank Prof Van Praag for having performed $\mathrm{Ca}, \mathrm{K}$ and $\mathrm{Mg}$ quantitations in his laboratory, and Prof Dizengremel for allowing access to the facilities for measuring Rubisco activity.

\section{REFERENCES}

Atkinson CJ (1991) The flux and distribution of xylem sap calcium to adaxial and abaxial epidermal tissue in relation to stomatal behaviour. $J$ Exp Bot $42,987-$ 993

Atkinson JC, Mansfield TA, Kean AM, Davies WJ (1989) Control of stomatal aperture by calcium in isolated epidermal tissue and whole leaves of Commelina communis L. New Phytol 111, 9-17

Atkinson JC, Mansfield TA, Davies WJ (1990) Does calcium in xylem sap regulate stomatal behaviour? New Phytol 116, 19-27

Balaguer L, Afif D, Dizengremel P, Dreyer E (1996) Ribulose bisphosphate carboxylase/oxygenase in an oak species (Quercus robur L): specificity and activities. Plant Physiol Biochem (in press)

Barnes JD, Balaguer L, Manrique E, Elvira S, Davison AW (1992) A reappraisal of the use of DMSO for the extraction and determination of chlorophylls-a and chlorophylls-b in lichens and higher plants. Environ Exp Bot 32, 85-100

Barr R, Troxel KS, Crane FL (1983) A calcium-selective site in photosystem II of spinach chloroplasts. Plant Physiol 73, 309-315

Barradas VL, Jones HG, Clark JA (1994) Stomatal responses to changing irradiance in Phaseolus vulgaris L. J Exp Bot 45, 931-936

Becker M, Lévy G (1982) Le dépérissement du chêne en Forêt de Tronçais. Les causes écologiques. Ann Sci For 39, 439-444

Blatt MR, Thiel G, Trentham DR (1990) Reversible inactivation of $\mathrm{K}^{+}$channels of Vicia faba stomatal guard cells following the photolysis of caged inositol 1,4,5triphosphate. Nature 346, 766-769

Bonneau M (1988) Le diagnostic foliaire. Rev For Fr 19 28

Bradford MM (1976) A rapid and sensitive method for the quantification of microgram quantities of protein utilizing the principle of protein-dye binding. Anal Biochem 72, 248-254

Davies WJ, Zhang J (1991) Roots signals and the regulation of growth and development of plants in drying soil. Annu Rev Plant Physiol 42, 55-76

De Silva DLR, Cox RC, Hetherington AM, Mansfield TA (1985) Suggested involvement of calcium and calmodulin in the responses of stomata to abscisic acid. New Phytol 101, 555-563

Epron D, Godard D, Cornic G, Genty B (1995) Limitations of net $\mathrm{CO}_{2}$ assimilation rates by internal resistances to $\mathrm{CO}_{2}$ transfer in leaves of two species (Fagus sylvatica $\mathrm{L}$ and Castanea sativa Mill). Plant Cell Environ $18,43-51$

Genty B, Briantais JM, Viera da Silva JB (1987) Effects of drought on primary photosynthetic processes of cotton leaves. Plant Physiol 83, 360-364

Genty B, Briantais JM, Baker NR (1989) The relationship between the quantum yield of photosynthetic electron transport and quenching of chlorophyll fluorescence. Biochem Biophys Acta 990, 87-92 
Gilroy S, Fricker MD, Read ND, Trewavas AJ (1991) Role of calcium in signal transduction of Commelina guard cells. Plant Cell 3, 333-344

Inoue $\mathrm{H}$, Katoh $\mathrm{Y}$ (1987) Calcium inhibits ion-stimulated stomatal opening in epidermal strips of Commelina communis L. J Exp Bot 38, 142-149

Kreimer G, Melkonian M, Holtum JAM, Latzko E (1985) Characterization of calcium fluxes across the envelope of intact spinash chloroplasts. Planta 166, 515-523.

Kreimer G, Melkonian M, Holtum JAM, Latzo E (1988) Stromal free calcium concentration and light-mediated activation of chloroplast fructose-1,6-bisphosphatase. Plant Physio/ 86, 423-428

Landmann G, Becker M, Delatour C, Dreyer E, Dupouey $\mathrm{JL}$ (1993) Oak dieback in France: historical and recent records, possible causes, current investigations. Rungespräche der Kommission für Ökologie, "Zustand und Gefährdung des Laubwälder" 5, 97-114

Lévy G, Becker M, Duhamel (1992) A comparison of the ecology of pedunculate and sessile oaks: radial growth in the Center and the North-West of France. For Ecol Manage 55, 51-63

Loreto F, Harley PC, Di Marco G, Sharkey TD (1992) Estimation of mesophyll conductance to $\mathrm{CO}_{2}$ flux by three different methods. Plant Physiol 98, 1437-1443

MacRobbie EAC (1988) Control of ion fluxes in stomatal guard cells. Bot Acta 101, 140-148

Mansfield TA, Hetherington AM, Atkinson CJ (1990) Some current aspects of stomatal physiology. Annu Rev Plant Physiol Plant Mol Biol 41, 55-75

McAinsh MR, Brownlee C, Hetherington AM (1990) Abscisic acid-induced elevation of guard cell cytosolic $\mathrm{Ca}^{2+}$ precedes stomatal closure. Nature $343,186-188$

Mei R, Yocum CF (1992) Comparative properties of hydroquinone and hydroxylamine reaction of the $\mathrm{Ca}^{2+}$-stabilized $\mathrm{O}_{2}$-evolving complex of Photosystem II: reductant-dependent $\mathrm{Mn}^{2+}$ formation and activity inhibition. Biochem 31, 8449-8454

Moore A, Akerman EO (1984) Calcium and plant organelles. Plant Cell Environ 7, 423-429

Peterson RB (1989) Partitioning of non-cyclic photosynthetic electron transport to $\mathrm{O}_{2}$-dependent dissipative processes as probed by fluorescence and $\mathrm{CO}_{2}$ exchange. Plant Physiol 90, 1322-1328

Poffenroth M, Green DB, Tallman G (1992) Sugar concentrations in guard cells of Vicia faba illuminated with red or blue light. Plant Physiol 98, 1460-1471

Ridolfi M, Garrec JP, Louguet P, Laffray D (1994) Effects of potassium and calcium deficiencies on stomatal functioning in intact leaves of Vicia faba L. Can J Bot 72, 1835-1842

Roupsard O. Gross P, Dreyer E (1996) Limitation of photosynthetic activity by $\mathrm{CO}_{2}$ availability in the chioroplasts of oak leaves from differents species and during drought. Ann Sci For 53, 243-254
Schroeder JI, Hagiwara S (1989) Cytosolic calcium regulates ion channels in the plasma membrane of Vicia faba guard cells. Nature $338,427-430$

Schwartz A (1985) Role of $\mathrm{Ca}^{2+}$ and EGTA on stomatal movements in Commelina communis L. Plant Physiol 79, 1003-1005

Shimazaki K, Terada J, Tanaka K, Kondo N (1989) Calvin-Benson cycle enzymes in guard cell protoplasts from Vicia faba L. Plant Physio/90, 1057-1064

Talbott LD, Zeiger E (1993) Sugar and organic acid accumulation in guard cells of Vicia faba in response to red and blue light. Plant Physiol 102, 1163-1169

Talliman G, Zeiger E (1988) Light quality and osmoregulation in Vicia guard cells. Plant Physiol 88, 887-895

Terashima I, Wong SC, Osmond CB, Farquhar GD (1988) Characterization of non-uniform photosynthesis induced by abscisic acid in the leaves having different mesophyll anatomies. Plant Cell Physiol 29, 385-395

Thimonier A, Dupouey JL, Bost F, Becker M (1994) Simultaneous eutropication and acidification of a forest ecosystem in North East France. New Phytol 126, 533-539

Tourneux C, Peltier G (1995) Effect of water deficit on the photosynthetic oxygen exchange measured using ${ }_{18} \mathrm{O}_{2}$ and mass flow spectrometry in Solanum tuberosum. Planta 195, 570-577

Ulrich E, Bonneau M (1994) État nutritionnel des peuplements du réseau RENECOFOR : brève synthèse de la première année d'échantillonnage et d'analyse (1993). In : La Santé des forêts (France) en 1993, ministère de l'Agiculture et de la Pêche (DERF. Département de la santé des forêts), $120 \mathrm{p}$

Valentini R, Epron D, De Angelis P, Matteucci G, Dreyer $E$ (1995) In situ estimation of net $\mathrm{CO}_{2}$ assimilation, photosynthetic electron flow and photorespiration in Turkey oak ( $Q$ cerris $L$ ) leaves: diurnal cycles under different levels of water supply. Plant Cell Environ $18,631-640$

Van Oosten JJ, Afif D, Dizengremel P (1992) Long-term effects of a $\mathrm{CO}_{2}$ enriched atmosphere on enzymes of the primary carbon metabolism of spruce trees. Plant Physiol Biochem 30, 541-547

Vavasseur A, Garrec JP, Laffray D (1984) Electronic microprobe study of variations in potassium concentration of stomatal complexes of two Commelinaceae. Physiol Vég 22, 841-849

von Caemmerer S, Farquhar GD (1981) Some relationships between the biochemistry of photosynthesis and the gas exchange of leaves. Planta 153, 376-387

Zemel E, Gepstein S (1985) Immunological evidence for the presence of ribulose bisphosphate carboxylase in guard cell chloroplasts. Plant Physiol 78, 586590 